\title{
Effect of hot water treatments and storage period on the quality attributes of banana (Musa sp.) fruit
}

\author{
Ajeet Kumar Kaka ${ }^{1}$, Khalil Ahmed Ibupoto' ${ }^{2}$, Shakeel Hussain \\ Chattha $^{2}$, Shakeel Ahmed Soomro ${ }^{2,3 *}$, Hafeez-ur-Rehman Mangio ${ }^{1}$, \\ Shahid Ahmed Junejo ${ }^{4}$, Aijaz Hussain Soomro ${ }^{5}$, Shehzor Gul \\ Khaskheli ${ }^{5}$ and Sandeep Kumar Kaka ${ }^{6}$ \\ 1. Department of Post-Harvest Technology \& Process Engineering, Khairpur College of Agricultural \\ Engineering and Technology, Khairpur Mir's-Pakistan \\ 2. Department of Farm Structures, Sindh Agriculture University, Tandojam-Pakistan \\ 3. College of Engineering, Nanjing Agricultural University, Nanjing 210031-China \\ 4. School of Tea Sciences \& Food Technology, Anhui Agricultural University, Hefei-China \\ 5. Institute of Food Sciences \& Technology, Sindh Agriculture University, Tandojam-Pakistan. \\ 6. Undergraduate Student, Khairpur College of Agricultural Engineering and Technology, Khairpur Mir's- \\ Pakistan \\ *Corresponding author's email: shakeelsoomro@live.com \\ Citation
}

Ajeet Kumar Kaka, Khalil Ahmed Ibupoto, Shakeel Hussain Chattha, Shakeel Ahmed Soomro, Hafeez-urRehman Mangio, Shahid Ahmed Junejo, Aijaz Hussain Soomro, Shehzor Gul Khaskheli and Sandeep Kumar Kaka. Effect of hot water treatments and storage period on the quality attributes of banana (Musa sp.) fruit. Pure and Applied Biology. Vol. 8, Issue 1, pp363-371. http://dx.doi.org/10.19045/bspab.2018.700195

\begin{tabular}{llll}
\hline \hline Received: 06/09/2018 & Revised: 20/11/2018 & Accepted: 30/11/2018 & Online First: 03/12/2018 \\
\hline \hline
\end{tabular}

\section{Abstract}

The current study was carried out to evaluate the effect of hot water treatments and storage period on quality attributes of banana in the laboratory of Farm Structures, Sindh Agriculture University, Tandojam, Pakistan during 2017. Green matured Basari banana fruit free from defects was collected from local fruit market. The samples of banana fruit were dipped for 10 minutes in four different water treatments i.e. control $\left(\mathrm{T}_{1}\right), 40^{\circ} \mathrm{C}\left(\mathrm{T}_{2}\right), 50^{\circ} \mathrm{C}\left(\mathrm{T}_{3}\right)$ and $60^{\circ} \mathrm{C}\left(\mathrm{T}_{4}\right)$. The quality attributes of stored banana fruits was observed at initial time of storage and at an interval of five days. The results demonstrated a significant $(\mathrm{p} \leq 0.05)$ effect of hot water treatments and storage period on banana's quality parameters. Highest values for moisture content (\%), pulp firmness $(\mathrm{N})$, pulp to peel ratio, titratable acidity (\%) and ash content (\%) were observed under $\mathrm{T}_{3}$ followed by $\mathrm{T}_{2}, \mathrm{~T}_{1}$ and $\mathrm{T}_{4}$, whereas least values for total soluble solids (\% brix), pulp pH, total sugar content (\%), decay incidence (\%) and weight loss (\%) were observed for $\mathrm{T}_{3}$ followed by $\mathrm{T}_{2}, \mathrm{~T}_{1}$ and $\mathrm{T}_{4}$. It was also observed that all quality attributes except moisture content, pulp firmness, titratable acidity and ash content increased with increasing storage period. The conducted study concluded that treatment $\mathrm{T}_{3}$ provided better results, maintaining better quality with minimum losses.

Keywords: Basari; Banana; Hot water treatments; Quality attributes; Storage period

\section{Introduction}

Banana (Musa sp.) is an important and one of the world's oldest cultivated fruit [1]. It is the World's most popular fruit in terms of trade with a worldwide production of 145 million metric tons [2]. As a diet, it's an affluent source of carbohydrate with a calorific value of 67 calories per $100 \mathrm{~g}$ fruit [3]. Being a major fruit crop of Pakistan, it has an international commercial 
importance, however, its short shelf life seriously limits the marketing of the fruit, where extending banana shelf life could be a considerable commercially benefit to both exporters and retailers [4]. The quality of bananas rapidly declines when fully ripened. The ripe banana is soft and delicate with a post-harvest shelf life of 5- 10 days. Generally, the primary factors causing postharvest loss in fruits can be categorized in to mechanical, physiological, pathological or environmental factors [5]. Treatments such as fungicides, heat treatments and low temperature storage are being applied for extending the shelf life of banana, however nowadays, increased public concern over presence of chemical residues has progressively lead the adoption of heat treatment methods $[6,7]$.

Poor postharvest handling practices from farm to retail are considered to be the major factors influencing banana loss in supply chain [8]. External and internal appearance and market quality of bananas are influenced by several factors, including production practices [9]. Many storage techniques have been developed to extend the shelf life and prolong the freshness of banana for storage and exporting purposes. Cold storage of $13^{\circ} \mathrm{C}$ is practiced by developed nations to slow down fruit metabolism and therefore prolong senescence [10]. However, this is costly, and rapid fruit re-warm on the display shelves tend to reduce shelf life [11]. Modified atmosphere packaging and ethylene absorbent packaging have also been suggested as substitutes for low temperature storage, however, these

Table 1. Hot water treatments

\begin{tabular}{|c|c|}
\hline Symbol & Treatment \\
\hline $\mathrm{T}_{1}$ & Control (untreated hot water treatment) \\
\hline $\mathrm{T}_{2}$ & $40^{\circ} \mathrm{C}$ hot water \\
\hline $\mathrm{T}_{3}$ & $50^{\circ} \mathrm{C}$ hot water \\
\hline $\mathrm{T}_{4}$ & $60^{\circ} \mathrm{C}$ hot water \\
\hline
\end{tabular}

\section{Moisture content (\%)}

The moisture content in banana pulp was determined using oven dried method, keeping the sample in the oven at a storages are costly as it involves more labour for careful handling to prevent damage to bags and to keep the modified atmosphere conditions [12]. Heat treatment is one of the postharvest techniques which have been used as a plant quarantine procedure [13]. Fresh produce when treated with hot water resulted in better quality, which was significantly different from those fresh produce which were untreated [4]. The heated fruit as compared to nonheated fruit resulted in better quality attributes with longer shelf life [14]. The study keeping the above facts in view was carried out to investigate the effects of different hot water treatments and storage period on the quality attributes of banana fruit.

\section{Materials and methods}

The present study was carried out in the laboratory of Farm Structures, Faculty of Agricultural Engineering, Sindh Agriculture University, Tandojam, Pakistan during 2017. Selected green matured variety banana named Basari free from defects was collected from the local fruit market. The banana samples were washed thoroughly with distilled water to get rid of soil particles and other foreign matter from the surface of fruits. The samples of banana fruit were dipped with different hot water treatments (Table 1) for 10 minutes. Treated banana samples were then packed in $4 \mu \mathrm{m}$ polyethylene bags, and stored for 15 days under ambient condition. The quality of stored banana were observed in terms of the following characteristics at initial time of storage and at an interval of five days.

\section{Treatment}

$60^{\circ} \mathrm{C}$ hot water

temperature of $105^{\circ} \mathrm{C}$ for 24 hours. The moisture content percentage was calculated by following formula [15], 
M.C. $(\%)=\frac{\mathrm{W}_{\mathrm{f}}-\mathrm{W}_{\mathrm{d}}}{\mathrm{W}_{\mathrm{f}}} \times 100$

Where, M.C = Moisture content in (\%), $\mathrm{W}_{\mathrm{f}}$ = weight of fresh banana sample $(\mathrm{g})$ and $\mathrm{W}_{\mathrm{d}}$ = weight of oven dry banana sample $(\mathrm{g})$.

Pulp firmness (N)

The fruit pulp firmness was measured manually, using a hand held penetrometer (Model CL 700 A). Fruit samples were taken from each replication and dissected horizontally with the help of knife, the plunger of penetrometer was vertically placed into the pulp and pressed along the dissected area of fruit [16].

Determination of pulp to peel ratio (Pp) The pulp and peel were weighed separately with digital balance, the readings were expressed as pulp to peel ratio by using the following relation [15],

$$
\mathrm{Pp}=\frac{\text { Pulp weight }(\mathrm{g})}{\text { Peel weight }(\mathrm{g})}
$$

\section{Total soluble solids (\% Brix)}

The total soluble solids of fruit pulp was measured with the help of refractometer (Atago, japan) and reading was expressed in percentage (Brix). Refractometer before using was standardized with distilled water and was then adjusted to $0 \%$ Brix. 10 grams of pulp tissue was homogenized in $40 \mathrm{ml}$ distilled water in the blender jug, and was then filtered with cotton wool. The reading was recorded by pouring two drops of filtrate on the glass prism of the refractometer [17].

\section{Titratable acidity (\%)}

Titratable acidity (also known as total acidity) was determined by titrating the pulp concentration against $0.1 \mathrm{~N}$ sodium hydroxide $(\mathrm{NaOH})$ using phenolphthalein as indicator until the concentration changed to pink colour, the results were expressed as percentage of Malic acid in flesh pulp weight [18].

\section{Pupl pH}

Pulp $\mathrm{pH}$ was determined in the pulp juice with a digital $\mathrm{pH}$ meter. About 10 grams of samples from each replication were taken and blended separately into $40 \mathrm{ml}$ distilled water, preparing a concentration. After that, the probe of $\mathrm{pH}$ meter was dipped in concentration and readings were recorded [19].

\section{Total sugar content (\%)}

Exactly five grams of samples from each replication were taken into a beaker, adding $100 \mathrm{ml}$ of warm water for preparation of solution. The prepared solution was then stirred until all the soluble matters were dissolved and filtered through what man paper into a 250 volumetric flask. $100 \mathrm{ml}$ of the solution adding $10 \mathrm{ml}$ of diluted $\mathrm{HCl}$ was prepared and added to the conical flask, which was then boiled for $5 \mathrm{~min}$. The solution on cooling was neutralized to phenolphthalein with $10 \% \mathrm{NaOH}$. This solution was used for titration against Fehling's solution and reading was calculated as follow [20], $\operatorname{TSC}(\%)=$ Factor $(4.95) \times$ dilution $(250) \times$

\section{5.}

Ash content (\%)

It is a measure of the total amount of minerals presented within a food. Ash content was determined according to method [17]. Ten grams from each sample were weighed in a silica crucible. The crucible was then placed in muffle furnace and heated for about three to five hours at $600^{\circ} \mathrm{C}$. After heating, the samples were collected and cooled in desiccator and weighed. The percentage of ash content was calculated using following formula,

$$
\text { Ash }(\%)=\frac{\text { Weight of residue }(\mathrm{g})}{\text { Weight of sample taken }(\mathrm{g})} \times 100
$$

\section{Decay incidence $(\%)$}

Decay is one of the main factors limiting the storage and shelf life of fresh products. The signs of decay including fungal growth or rot spot was determined visually. The percentage of the decayed fruits was observed using the equation given below [21].

Decay incidence $(\%)=$ Number of infected fruits / Total number of fruits used x 100

\section{Weight loss (\%)}

Banana fruits were weighed before and after placing the samples in storage at an interval of five days. The weight was determined using sensitive balance (type 
DT 2K model Lark ® 511214). The percentage of weight loss was calculated using the expression given below [21].

Weight loss $(\%)=$ Initial weight $(\mathrm{g})$ Weight (g) at sampling date / Initial weight (g) x 100

\section{Statistical analysis}

Analysis of variance (ANOVA) was performed using two factorial design model and mean multiple comparison was carried out with least significant difference test at $5 \%$ probability level.

\section{Results and discussion \\ Moisture content (\%)}

Influence of hot water treatments on the moisture content of banana fruit is represented in (Table 2). It was noticed that average moisture content ranged between 68.24 to $69.18 \%$ with an average of $68.70 \%$. The highest banana moisture content was recorded under treatment $\mathrm{T}_{3}$, followed by $T_{2}$ and $T_{1}$ respectively, whereas lowest moisture content recorded was observed with treatment $\mathrm{T}_{4}$. The initial average moisture content of Basari fruit was observed to be $73.07 \%$ which decreased with passage of time. Decreasing trend of moisture content was due to higher respiration rate during storage and was also observed by John and Marchall [22].

\section{Pulp firmness (N)}

Table 3 shows the influence of hot water treatments on the fruit pulp firmness of banana fruits. Pulp firmness of Basari banana variety ranged between 4.63 to 5.11 $\mathrm{N}$. The highest banana fruit pulp firmness with $5.11 \mathrm{~N}$ was observed under $\mathrm{T}_{3}\left(50^{\circ} \mathrm{C}\right.$ hot water dip for 10 minutes), followed by $\mathrm{T}_{2}$, and $\mathrm{T}_{1}$, where minimum with $4.63 \mathrm{~N}$ was observed under treatment $\mathrm{T}_{4}$. The average initial pulp firmness of banana was observed to be $7.04 \mathrm{~N}$, which decreased with increasing days of storage. The average decrease in pulp firmness of Basari banana after 15 days was observed to be $2.15 \mathrm{~N}$. Decreasing trend in fruit pulp firmness during storage was due to solubilization of peptic substances in the cell wall and middle lamella, which was also reporte by Dadzie [23].

\section{Pulp to peel ratio $(\mathbf{P p})$}

A significant difference was observed for banana when treated with different treatments (Table 4). It was noticed that pulp/peel ratio of Basari ranged between 2.08 to 2.29 with an average of average of 2.18. The highest banana pulp/peel ratio with 2.29 was recorded under $\mathrm{T}_{3}\left(50^{\circ} \mathrm{C}\right.$ hot water dip for 10 minutes), followed by $\mathrm{T}_{2}$, $\mathrm{T}_{1}$ and $\mathrm{T}_{4}$ with $2.21,2.14$ and 2.08 respectively. Initial pulp/peel ratio of Basari fruit was observed to be1.81 which after 15 days of storage increased to 2.86. It was observed that pulp/peel ratio simultaneously increased with increasing storage time. Fallik [13] stated that heat treatment is one of those postharvest techniques which have been used as a plant quarantine procedure in mango, banana, apple, avocado, and litchi, which indeed maintains the quality of fresh produce. Decrease in moisture content and pulp / peel ratio during initial days was due to breakdown of carbohydrates and osmotic transfer from peel into pulp, which has also been reported by Castelo-branco et al. [24]. Total soluble solids ( \% Brix)

Table 5 represents the effect of hot water treatments on total soluble solids of banana fruit. It was observed that total soluble solid of Basari ranged between 13.50 to $15.60 \%$ with average of $14.65 \%$. The highest banana total soluble solid with $15.60 \%$ was observed under $\mathrm{T}_{4}\left(60^{\circ} \mathrm{C}\right.$ hot water dip for 10 minutes), followed by $\mathrm{T}_{1}$ and $\mathrm{T}_{2}$, whereas minimum total soluble solids with $13.50 \%$ was observed for treatment $\mathrm{T}_{3}$. It was observed that the total soluble solids increased with increasing days, initial total soluble solids was observed to be $10.09 \%$ which with passage of time increased to $19.55 \%$. Increase in total soluble solids was due to breakdown of starch into soluble sugars [10]. Similar findings has also been reported by Yap et al. [25].

\section{Titratable acidity (\%)}

Banana's quality had significantly been effected $(p \leq 0.05)$ when treated with different hot water temperature and storage period (Table 6). Basari banana under 
treatment $\mathrm{T}_{3}$ resulted highest titratable acidity $(0.57 \%)$, where with $0.44 \%$ (minimum) it was observed under treatment $\mathrm{T}_{4}$. Initial average titratable acidity of Basari banana was observed to be $0.74 \%$, which with increasing storage decreased to $0.30 \%$. Decrease in titratable acidity was due to increase in total soluble solids [26]. High temperature which increases the rate of respiration in fruits results subsequently to the breakdown of the inner tissues, the results are in line with the findings of Kader [27].

\section{Pulp pH}

The influence of hot water treatments on pulp $\mathrm{pH}$ of banana fruit is represented in (Table 7). The pulp $\mathrm{pH}$ of Basari banana ranged from 5.32 to 5.78 , with an average of 5.54. The highest banana pulp $\mathrm{pH}$ of 5.78 was observed under treatment $\mathrm{T}_{4}\left(60^{\circ} \mathrm{C}\right.$ hot water dip for 10 minutes), followed by $\mathrm{T}_{1}$ (control) and $\mathrm{T}_{2}\left(40^{\circ} \mathrm{C}\right.$ hot water dip for 10 minutes), whereas lowest pulp $\mathrm{pH}$ with 5.32 was observed under treatment $\mathrm{T}_{3}\left(50^{\mathrm{O}} \mathrm{C}\right.$, hot water dip for 10 minutes). Pulp $\mathrm{pH}$ with increasing storage days increased from 4.62 (initial) to 6.22 (after 15 days of storage). Increase in pulp $\mathrm{pH}$ relates to the increasing titratable acidity. These findings are parallel with the study of Kyu Kyu Win et al. [28], whom for banana obtained similar results and stated that the quality of bananas rapidly declined when fully ripened.

\section{Total sugar content (\%)}

Table 8 shows the influence of hot water treatments on total sugar content of Basari banana fruit, which were observed to be statistically different $(\mathrm{p} \leq 0.05)$. Total sugar content of Basari banana ranged from 8.94 to $10.33 \%$, with an average of $9.62 \%$. The highest total sugar content with $10.33 \%$ was observed under treatment $\mathrm{T}_{4}$, followed by $\mathrm{T}_{1}$ with $9.75 \%, \mathrm{~T}_{2}$ with 9.45 and $\mathrm{T}_{3}$ with 8.94 (minimum). An increase in total sugar content was observed with increasing storage days for all treatments. Prasajith et al. [29], reported that total sugar content in fruits showed an increased trend that was due to the rapid induction of pre-climacteric and climacteric phases, where Marriot and
Palmer [30] observed same that was due to climacteric peak in respiratory metabolic pathways in starch hydrolysis.

\section{Ash content (\%)}

Ash content when observed was significantly affected by hot water treatments. Ash content as influenced by hot water treatments are represented in (Table 9). Ash content of Basari banana ranged from 3.65 to $4.02 \%$, with an average of $3.84 \%$. The highest ash content with 4.02 $\%$ was observed under treatment $\mathrm{T}_{3}\left(50^{\circ} \mathrm{C}\right.$, hot water dip for 10 minutes), followed by $\mathrm{T}_{2}, \mathrm{~T}_{1}$ and $\mathrm{T}_{4}$. Average ash content was initially observed to be $5.19 \%$, which with increasing days of storage reduced to 2.96 $\%$.Similar finding in reduction of ash content with respect to increasing days in storage has also been reported by Varit and Songsin [4] and Blessing et al [31].

\section{Decay incidence $(\%)$}

Hot water treatments and storage period had a significant $(\mathrm{p} \leq 0.05)$ effect on decay incidence of Basari banana fruit (Table 10). Highest decay incidence was observed under treatment $\mathrm{T}_{4}$ with $15.81 \%$, followed by $\mathrm{T}_{1}$ with $15.38 \%, \mathrm{~T}_{2}$ with $13.66 \%$ and minimum for $\mathrm{T}_{3}$ with $8.88 \%$. The decay incidence ranged between 8.88 to $15.81 \%$ with an average of $13.43 \%$. Decay incidence while keeping the samples in storage was $0.00 \%$ which then with increasing days of storage averagely increased to $24.55 \%$. Similar loss of decay incidence has also been reported by Paul and Chen [7], where Lurie [6] observing same stated that postharvest heat treatments of fruit have been used for insect disinfestations, enhancement of fruit tolerances to other stress and also maintenance of fruit quality during storage. Weight loss (\%)

Table 11 shows the influence of hot water treatments on the weight loss of Basari banana fruit. Weight loss of Basari banana ranged between 7.60 to $9.13 \%$, with an average of $8.36 \%$. The highest banana weight loss was observed under treatment $\mathrm{T}_{4}\left(60^{\circ} \mathrm{C}\right.$, hot water dip for 10 minutes $)$, followed by $T_{1}$ and $T_{2}$, whereas lowest with 
$7.60 \%$ was observed for treatment $\mathrm{T}_{3}$. Average weight loss of Basari banana reduced with increasing days of storage, which with a maximum average was observed to be $14.88 \%$. The higher weight loss in treated fruits were due to the upsurge in the respiration rates by fruits during the storage, accelerated evaporation rate from surface of fruits and burning of tissues of fruit surfaces [32]. Similar weight loss for banana has also been reported by Mahajan et al. [33].

Table 2. Moisture content (\%) of banana fruit as influenced by different hot water treatments and storage period

\begin{tabular}{|c|c|c|c|c|c|}
\hline \multirow{2}{*}{ Treatment } & \multicolumn{4}{|c|}{ Storage period } & \multirow{2}{*}{ Mean } \\
\cline { 2 - 5 } & 0 day & 05 day & 10 day & 15 day & $68.56^{\mathrm{C}}$ \\
\hline $\mathrm{T}_{1}$ & 73.90 & 68.83 & 66.76 & 64.76 & $68.82^{\mathrm{B}}$ \\
\hline $\mathrm{T}_{2}$ & 72.80 & 69.56 & 67.48 & 65.45 & $69.18^{\mathrm{A}}$ \\
\hline $\mathrm{T}_{3}$ & 72.20 & 70.26 & 68.16 & 66.11 & $68.24^{\mathrm{D}}$ \\
\hline $\mathrm{T}_{4}$ & 73.40 & 68.56 & 66.51 & 64.51 & \\
\hline Mean & $73.07^{\mathrm{A}}$ & $69.30^{\mathrm{B}}$ & $67.22^{\mathrm{C}}$ & $65.21^{\mathrm{D}}$ & \\
\hline
\end{tabular}

Table 3. Pulp firmness (N) of banana fruit as influenced by different hot water treatments and storage period

\begin{tabular}{|c|c|c|c|c|c|}
\hline \multirow{2}{*}{ Treatment } & \multicolumn{4}{|c|}{ Storage period } & \multirow{2}{*}{ Mean } \\
\cline { 2 - 5 } & 0 day & 05 day & $\mathbf{1 0}$ day & $\mathbf{1 5}$ day & $4.81^{\mathrm{C}}$ \\
\hline $\mathrm{T}_{1}$ & 7.03 & 5.89 & 4.21 & 2.09 & $4.95^{\mathrm{B}}$ \\
\hline $\mathrm{T}_{2}$ & 7.06 & 6.02 & 4.52 & 2.18 & $5.11^{\mathrm{A}}$ \\
\hline $\mathrm{T}_{3}$ & 7.06 & 6.35 & 4.71 & 2.31 & $4.63^{\mathrm{D}}$ \\
\hline $\mathrm{T}_{4}$ & 7.01 & 5.47 & 4.02 & 2.00 & \\
\hline Mean & $7.04^{\mathrm{A}}$ & $5.93^{\mathrm{B}}$ & $4.37^{\mathrm{C}}$ & $2.15^{\mathrm{D}}$ & \\
\hline
\end{tabular}

Table 4. Pulp/Peel ratio of banana fruit as influenced by different hot water treatments and storage period

\begin{tabular}{|c|c|c|c|c|c|}
\hline \multirow{2}{*}{ Treatment } & \multicolumn{4}{|c|}{ Storage period } & \multirow{2}{*}{ Mean } \\
\cline { 2 - 5 } & 0 day & 05 day & 10 day & 15 day & $2.14^{\mathrm{C}}$ \\
\hline $\mathrm{T}_{1}$ & 1.81 & 1.83 & 2.12 & 2.81 & $2.21^{\mathrm{B}}$ \\
\hline $\mathrm{T}_{2}$ & 1.83 & 1.87 & 2.23 & 2.90 & $2.29^{\mathrm{A}}$ \\
\hline $\mathrm{T}_{3}$ & 1.80 & 1.95 & 2.31 & 3.10 & $2.08^{\mathrm{D}}$ \\
\hline $\mathrm{T}_{4}$ & 1.81 & 1.83 & 2.04 & 2.62 & \\
\hline Mean & $1.8^{\mathrm{D}}$ & $1.87^{\mathrm{C}}$ & $2.18^{\mathrm{B}}$ & $2.86^{\mathrm{A}}$ & \\
\hline
\end{tabular}

Table 5. Total soluble solids (\% Brix) of banana fruit as influenced by different hot water treatments and storage period

\begin{tabular}{|l|l|l|l|l|l|}
\hline \multirow{2}{*}{ Treatment } & \multicolumn{3}{|l|}{ Storage period } & \multirow{2}{*}{ Mean } \\
\cline { 2 - 6 } & 0 day & 05 day & 10 day & $\mathbf{1 5}$ day & $15.19^{\mathrm{B}}$ \\
\hline $\mathrm{T}_{1}$ & 10.40 & 13.20 & 16.40 & 20.76 & $14.32^{\mathrm{C}}$ \\
\hline $\mathrm{T}_{2}$ & 9.86 & 12.76 & 15.80 & 18.86 & $13.50^{\mathrm{D}}$ \\
\hline $\mathrm{T}_{3}$ & 9.20 & 12.20 & 15.20 & 17.40 & $15.60^{\mathrm{A}}$ \\
\hline $\mathrm{T}_{4}$ & 10.90 & 13.76 & 16.60 & 21.16 & \\
\hline Mean & $10.09^{\mathrm{D}}$ & $12.98^{\mathrm{C}}$ & $16.00^{\mathrm{B}}$ & $19.55^{\mathrm{A}}$ & \\
\hline
\end{tabular}


Table 6. Titratable Acidity (\%) of banana fruit as influenced by different hot water treatments and storage period

\begin{tabular}{|c|c|c|c|c|c|}
\hline \multirow{2}{*}{ Treatment } & \multicolumn{4}{|c|}{ Storage period } & \multirow{2}{*}{ Mean } \\
\cline { 2 - 5 } & 0 day & 05 day & 10 day & 15 day & $0.48^{\mathrm{C}}$ \\
\hline $\mathrm{T}_{1}$ & 0.71 & 0.53 & 0.40 & 0.28 & $0.55^{\mathrm{B}}$ \\
\hline $\mathrm{T}_{2}$ & 0.80 & 0.58 & 0.47 & 0.33 & $0.57^{\mathrm{A}}$ \\
\hline $\mathrm{T}_{3}$ & 0.72 & 0.65 & 0.52 & 0.37 & $0.44^{\mathrm{D}}$ \\
\hline $\mathrm{T}_{4}$ & 0.73 & 0.50 & 0.32 & 0.21 & \\
\hline Mean & $0.74^{\mathrm{A}}$ & $0.57^{\mathrm{B}}$ & $0.43^{\mathrm{C}}$ & $0.30^{\mathrm{D}}$ & \\
\hline
\end{tabular}

Table 7. Pulp pH of banana fruit as influenced by different hot water treatments and storage period

\begin{tabular}{|c|c|c|c|c|c|}
\hline \multirow{2}{*}{ Treatment } & \multicolumn{4}{|c|}{ Storage period } & \multirow{2}{*}{ Mean } \\
\cline { 2 - 5 } & 0 day & 05 day & 10 day & 15 day & $5.59^{\mathrm{B}}$ \\
\hline $\mathrm{T}_{1}$ & 4.58 & 5.42 & 6.05 & 6.30 & $5.49^{\mathrm{C}}$ \\
\hline $\mathrm{T}_{2}$ & 4.74 & 5.39 & 5.82 & 6.00 & $5.32^{\mathrm{D}}$ \\
\hline $\mathrm{T}_{3}$ & 4.65 & 5.29 & 5.57 & 5.75 & $5.78^{\mathrm{A}}$ \\
\hline $\mathrm{T}_{4}$ & 4.52 & 5.48 & 6.32 & 6.81 & \\
\hline Mean & $4.62^{\mathrm{D}}$ & $5.40^{\mathrm{C}}$ & $5.94^{\mathrm{B}}$ & $6.22^{\mathrm{A}}$ & \\
\hline
\end{tabular}

Table 8. Total sugar content of banana fruit as influenced by different hot water treatments and storage period

\begin{tabular}{|c|c|c|c|c|c|}
\hline \multirow{2}{*}{ Treatment } & \multicolumn{4}{|c|}{ Storage period } & \multirow{2}{*}{ Mean } \\
\cline { 2 - 5 } & 0 day & 05 day & 10 day & 15 day & 15.47 \\
\hline $\mathrm{T}_{1}$ & 4.21 & 6.75 & 12.58 & $15.45^{\mathrm{B}}$ \\
\hline $\mathrm{T}_{2}$ & 4.45 & 5.91 & 12.76 & 14.66 & $9.45^{\mathrm{C}}$ \\
\hline $\mathrm{T}_{3}$ & 4.87 & 5.17 & 11.90 & 13.80 & $8.94^{\mathrm{D}}$ \\
\hline $\mathrm{T}_{4}$ & 4.02 & 7.20 & 13.10 & 16.99 & $10.33^{\mathrm{A}}$ \\
\hline Mean & $4.39^{\mathrm{D}}$ & $6.26^{\mathrm{C}}$ & $12.59^{\mathrm{B}}$ & $15.23^{\mathrm{A}}$ & \\
\hline
\end{tabular}

Table 9. Ash content of banana fruit as influenced by different hot water treatments and storage period

\begin{tabular}{|c|c|c|c|c|c|}
\hline \multirow{2}{*}{ Treatment } & \multicolumn{4}{|c|}{ Storage period } & \multirow{2}{*}{ Mean } \\
\cline { 2 - 5 } & 0 day & 05 day & 10 day & 15 day & $3.78^{\mathrm{C}}$ \\
\hline $\mathrm{T}_{1}$ & 4.91 & 3.73 & 3.50 & 2.98 & $3.88^{\mathrm{B}}$ \\
\hline $\mathrm{T}_{2}$ & 5.82 & 3.55 & 3.33 & 2.84 & $4.02^{\mathrm{A}}$ \\
\hline $\mathrm{T}_{3}$ & 4.64 & 4.19 & 3.93 & 3.35 & $3.65^{\mathrm{C}}$ \\
\hline $\mathrm{T}_{4}$ & 5.40 & 3.37 & 3.16 & 2.69 & \\
\hline Mean & $5.19^{\mathrm{A}}$ & $3.71^{\mathrm{B}}$ & $3.48^{\mathrm{C}}$ & $2.96^{\mathrm{D}}$ & \\
\hline
\end{tabular}

Table 10. Decay incidence of banana fruit as influenced by different hot water treatments and storage period

\begin{tabular}{|c|c|c|c|c|c|}
\hline \multirow{2}{*}{ Treatment } & \multicolumn{4}{|c|}{ Storage period } & \multirow{2}{*}{ Mean } \\
\cline { 2 - 5 } & 0 day & 05 day & $\mathbf{1 0}$ day & $\mathbf{1 5}$ day & $15.38^{\mathrm{B}}$ \\
\hline $\mathrm{T}_{1}$ & 0.00 & 15.36 & 18.90 & 27.26 & $13.66^{\mathrm{C}}$ \\
\hline $\mathrm{T}_{2}$ & 0.00 & 13.16 & 16.19 & 25.27 & $8.88^{\mathrm{D}}$ \\
\hline $\mathrm{T}_{3}$ & 0.00 & 8.55 & 10.52 & 16.43 & $15.81^{\mathrm{A}}$ \\
\hline $\mathrm{T}_{4}$ & 0.00 & 15.23 & 18.74 & 29.25 & \\
\hline Mean & $0.00^{\mathrm{D}}$ & $13.08^{\mathrm{C}}$ & $16.09^{\mathrm{B}}$ & $24.55^{\mathrm{A}}$ & \\
\hline
\end{tabular}


Table 11. Weight loss of banana fruit as influenced by different hot water treatments and storage period

\begin{tabular}{|c|c|c|c|c|c|}
\hline \multirow{2}{*}{ Treatment } & \multicolumn{4}{|c|}{ Storage period } & \multirow{2}{*}{ Mean } \\
\cline { 2 - 5 } & 0 day & $\mathbf{0 5}$ day & $\mathbf{1 0}$ day & 15 day & $8.60^{\mathrm{B}}$ \\
\hline $\mathrm{T}_{1}$ & 0.0 & 5.72 & 13.5 & 15.18 & $8.11^{\mathrm{C}}$ \\
\hline $\mathrm{T}_{2}$ & 0.0 & 5.43 & 12.6 & 14.40 & $7.60^{\mathrm{D}}$ \\
\hline $\mathrm{T}_{3}$ & 0.0 & 5.26 & 11.3 & 13.84 & $9.13^{\mathrm{A}}$ \\
\hline $\mathrm{T}_{4}$ & 0.0 & 6.10 & 14.3 & 16.10 & \\
\hline Mean & $0.00^{\mathrm{D}}$ & $5.63^{\mathrm{C}}$ & $12.93^{\mathrm{B}}$ & $14.88^{\mathrm{A}}$ & \\
\hline
\end{tabular}

\section{Conclusion}

The study concluded that, the hot water treatment with storage period when observed had a significant effect on the quality attributes of Basari banana fruit. Banana when treated with $50^{\circ} \mathrm{C}$, hot water dip for 10 minutes resulted highest values for moisture content (\%), pulp firmness $(\mathrm{N})$, pulp to peel radio, titratable acidity (\%), ash content (\%) and lowest values for total soluble solids (\% Brix), pulp pH, total sugar content $(\%)$, decay incidence $(\%)$ and weight loss (\%). Furthermore it was also observed that quality attributes leaving moisture content, pulp firmness, titratable acidity and ash content increased with increasing days of storage. This study strongly suggest the farmers and stockholders to adopt this hot water processing $\left(50^{\circ} \mathrm{C}\right.$, hot water dip for 10 minutes) technique to improve the quality attributes of banana along with increasing its shelf life.

\section{Authors' contributions}

Conceived and designed the experiments: AK Kaka \& KA Ibupoto, Performed the experiments: AK Kaka, SH Chattha \& SG Khaskheli, Analyzed the data: AK Kaka, SH Chattha, SA Soomro, HR Mangio and AH Soomro, Contributed reagents/ materials/ analysis tools: KA Ibupoto, SA Junejo, AH Soomro, SG Khaskheli \& SD Kaka, Wrote the paper: AK Kaka \& SA Soomro.

\section{References}

1. Kumar KPS, Bhowmik D, Duraivel S \& Umadevi M (2012). Traditional and medicinal uses of banana. J Pharmacogn Phytochem 1(3): 51-63.
2. FAO (2014) Banana market review and banana statistics 2012-2013, Rep. I3627E/1/01.14. FAO, Rome.

3. Emaga TH, Andrianaivo RH, Wathelet B, Tchango JT \& Paquot M (2008). Effects of the stage of maturation and varieties on the chemical composition of banana and plantain peels. Food Chem 103(2): 590600.

4. Varit S \& Songsin P (2011). Effects of hot water treatments on the physiology and quality of 'Kluai Khai' banana. Int Food Res J 18(3):1013-1016.

5. Kader AA \& Rolle RS (2004). The role of post-harvest management in assuring the quality and safety of horticultural produce, Vol 152. FAO, Rome.

6. Lurie S (1998). Postharvest heat treatments, Postharvest Biol Technol 14(3): 257-269.

7. Paull RE \& Chen NJ (2000). Heat treatment and fruit ripening. Postharvest Biol Technol 21(1): 21-37.

8. Mebratie MA, Haji J, Woldetsadik K \& Ayalew A (2015). Determinants of Postharvest Banana Loss in the Marketing Chain of Central Ethiopia. Food Sci Qual Manag 37: 52-63.

9. Santosh DT, Tiwari KN \& Reddy RG (2017). Banana Bunch Covers for Quality Banana Production - A Review. Int J Curr Microbiol Appl Sci 6(7): 1275-1291.

10. Reyes MEQ, NishijimaW \& Paull RE (1998). Control of crown rot in 'San Catarina Prata' and 'Williams' banana with hot water treatments. Postharvest Biol Technol 14(1): 71-75.

11. Klieber A, Bagnato $N$, Barrett $R$ \& Sedgley M (2002). Effect of post-ripening nitrogen atmosphere storage on banana shelf life, visual appearance and aroma. Postharvest Biol Technol 25(1): 5-24. 
12. Scott KJ, McGlasson WB \& Roberts EA (1970). Potassium permanganate as an ethylene absorbent in polyethylene bags to delay ripening of bananas during storage. Aust J Exp Agric Anim Husb 10(43): 237240.

13. Fallik E (2004). Pre-storage hot water treatments (immersion, rinsing and brushing). Postharvest Biol Technol 32(2): 125-134.

14. Klein JD \& Lurie S (1992). Heat Treatments for Improved postharvest quality of horticultural crops. Hort Technol 2(3): 316-320.

15. Tapre AR \& Jain RK (2012). Study of advanced maturity stages of banana. Int $J$ Adv Eng Res Stud 1(3): 272-274.

16. Chancharoenrit J (2002). Effects of hot water dips on physiological changes and chilling injury after storage of 'Hom Thong' variety of banana. Master's Thesis, Department of Botany, Faculty of Science, Chulalongkorn University, Bangkok, Thailand.

17. AOAC. 1984. Official Methods of Analysis. 14th ed. Association of Official Analytical Chemists. Arlington, Virginia, USA.

18. AOAC, 2005. Official methods of Analysis, 18th Edu.,Association of official Analytical Chemists, Washington, D C., USA.

19. Ranganna S (1986). Handbook of Analysis and Quality Control for Fruits and Vegetables, Tata McGraw Hill Ltd., New Delhi, India, p. 1112.

20. SMRI (1997). Determination of the reducing sugars in juice by the Lane and Eynon method. SMRI Test Methods, TM047.

21. Soomro SA, Ibupoto KA, Soomro NM \& Jamali LA (2016). Effect of storage methods on the quality of onion bulbs. Pak J Agri Agril Engg Vet Sci 32(2): 221-228.

22. John P \& Marchal. J (1995). Ripening and biochemistry of the fruit. In: Gowen, S.R. (ed.). Bananas and Plantains, Chapman and Hall, London, UK.

23. Dadzie BK \& Orchard JE (1997). Routine Post Harvest Screening of Banana/Plantain Hybrids: Criteria and Methods. INIBAP Technical Guidelines 2, Wageningen, The Netherlands.
24. Castelo-branco VN., Guimarães JN, Souza L, Guedes MR, Silva PM, Ferrão LL, Miyahira RF, Guimarães RR, Freitas SML, Reis MC \& Zago L (2017). The use of green banana (Musa balbisiana) pulp and peel flour as an ingredient for tagliatelle pasta. Brazilian J Food Technol 20: e2016119.

25. Yap M, Fernando WMADB, Brennan CS, Jayasena V \& Coorey R (2017). The effects of banana ripeness on quality indices for puree production. LWT - Food Sci Technol 80: 10-18.

26. Seymour GB, Taylor JE \& Tucker GA (1993). Biochemistry of fruit ripening (Banana. pp 83-106). Chapman \& Hall, London.

27. Kader AA (2005). Increasing food availability by reducing postharvest losses of fresh produce. Proc. 5th Int. Postharvest Symp. Acta Horticul 682: 2169-2176.

28. Kyu Kyu Win $\mathrm{N}$, Jitareerat $\mathrm{P}$, Kanlayanarat S \& Sangchote S (2007). Effects of cinnamon extract, chitosan coating, hot water treatment and their combinations on crown rot disease and quality of banana fruit. Postharvest Biol Technol 45(3): 333-340.

29. Prasajith KD, Dissanayake MLM \& Wijesekara UM (2015). Effect of hot water treatments on postharvest life of seeni kesel banana (Musa spp. cv. Seeni keselpisang awak, ABB). J Agric Ecol Res Int 2(4): 209-218.

30. Marriott J \& Palmer JK (1980). Bananasphysiology and biochemistry of storage and ripening for optimum quality. Crit Rev Food Sci Nutr 13(1): 41-88.

31. Blessing I, Opens O \& Ekwunife OA (2015). Production and evaluation of the physico-chemical and sensory qualities of mixed fruit leather and cakes produced from apple (Musa Pumila), banana (Musa sapientum), pineapple (Ananas comosus). J Food Sci 11(1): 951-955.

32. Singh UR, Singh G \& Khan A (1977). Studies on the artificial ripening of banana cultivars Basari dwarf. Hort 9(1): 53-59.

33. Mahajan BVC, Singh G \& Dhatt AS (2008). Studies on ripening behaviour and quality of winter guava with ethylene gas ethephon treatments. J Food Sci Technol 45:81-84. 